\title{
Voice but No Choice-Children's Right to Participation in Sweden
}

\author{
Pernilla Leviner
}

This chapter will deal with what role children's right to participation plays in Swedish law and the connection between this right and the Instrument of Government (Regeringsformen, 1974:152), which is one of four statutes with constitutional status in Sweden. ${ }^{1}$ Two aspects of children's right to participation are analysed. First participation for children from a 'democracy perspective', or in other words participation as a collective right for children to influence public decision-making - here specifically the right to vote, and secondly children's right to be heard in the Swedish child protection system, which can be seen as an example on how the right to participation has been implemented into national Swedish law affecting children in individual cases.

There are other examples of both collective rights, also including children, to participate in public decision-making, see for example freedom of expression, information, assembly and the freedom to demonstrate, ${ }^{2}$ partly discussed by Titti Mattsson in this volume, ${ }^{3}$ and also other areas of law in which children have the right to be heard in individual cases, for example family law and migration law. The reason to focus here specifically on the right to vote and the right to be heard as implemented in child protection regulations are partly pragmatic and out of interest, but these specific rights can be argued to be 'two sides of the same coin'. The right to vote can be claimed to be the most basic political

1 I want to thank Titti Mattsson and Johanna Schiratzki, authors of the othter chapters on Sweden in this book, Aoife Daly and Vera Yllner for their valuable comments as to previous drafts. Thanks are also given to the editors of this book and the anonymous reviewer for helpful comments. Any errors or mistakes remaining however are clearly my own.

2 These rights are protected by the Instrument of Government chapter 2, section 1 and the Freedom of the Press Act (Tryckfrihetsförordning, 1949:105) and the Fundamental Law on Freedom of Expression (Yttrandefrihetsgrundlagen, 1991:1469). See also the UN Convention on the Rights of the Child, articles 13-15.

3 Titti Mattsson, 'Constitutional Rights for Children in Sweden' in Trude Haugli and others (eds), Children's Constitutional Rights in the Nordic Countries (Brill 2019).

(C) PERNILLA LEVINER, 2020 | DOI:10.1163/9789004382817_015

This is an open access chapter distributed under the terms of the CC-BY-NC 4.o bicenseta Leviner - 9789004382817 
right of all and therefore an important example of a collective participatory right, whereas the right for children to be heard in child protection cases deals with decisions of clear, even life-changing, importance for the individual child.

When talking about children's right to participation, article 12 of the UN Convention on the Rights of the Child (the CRC), ${ }^{4}$ often referred to as the participation article, is a natural starting-point. According to the UN Committee on the Rights of the Child (the UN Committee), article 12 establishes the following:

... the right of every child to freely express her or his views, in all matters affecting her or him, and the subsequent right for those views to be given due weight, according to the child's age and maturity. This right imposes a clear legal obligation on States parties to recognize this right and ensure its implementation by listening to the views of the child and according them due weight. This obligation requires that States parties, with respect to their particular judicial system, either directly guarantee this right, or adopt or revise laws so that this right can be fully enjoyed by the child. ${ }^{5}$

The CRC also stipulates what can be described as more general collective participation rights in articles 13-15, emphasising children's right to freedom of expression, freedom of thought, conscience and religion as well as freedom of association and peaceful assembly. ${ }^{6}$

It can be noted that efforts have been made in Sweden to emphasise children's rights generally on the constitutional level. The Swedish Instrument of Government was reformed in 2011 to include a goal-oriented provision in chapter 1, section 2 stating that public institutions have a specific responsibility to safeguard children's rights, but participation is not specifically

4 Article 12 reads as follows: 1. States Parties shall assure to the child who is capable of forming his or her own views the right to express those views freely in all matters affecting the child, the views of the child being given due weight in accordance with the age and maturity of the child. 2. For this purpose, the child shall in particular be provided the opportunity to be heard in any judicial and administrative proceedings affecting the child, either directly, or through a representative or an appropriate body, in a manner consistent with the procedural rules of national law.

5 UN Committee on the Rights of the Child, General comment no. 12: The right of the child to be heard (1 July 2009) CRC/C/GC/12 para 15 .

6 See for international discussion for example Aoife Daly, A Commentary on the United Nations Convention on the Rights of the Child, Article 15: The Right to Freedom of Association and Peaceful Assembly (Brill Nijhofff 2016). 
mentioned. ${ }^{7}$ In June 2018, the Swedish parliament decided to incorporate the CRC into Swedish law and the need to strengthen children's right to participation was emphasised in the legislative bill. ${ }^{8}$ However, incorporation will be done without giving the convention constitutional status or protection and what effects incorporation will have, both in general and when it comes to children's right to participation more specifically, remains to be seen. ${ }^{9}$ Apart from the reform of the Instrument of Government and the incorporation of the CRC, several statutes, such as the Social Services Act and the Parental Code, have been reformed with the specific aim being to strengthen children's right to participation in line with the CRC. ${ }^{10}$ However, although having the overall aim to strengthen children's right to participation, it can be concluded that it has not been clear what these reforms have actually wanted to achieve, and at what cost in the sense how specific children's rights would need to be balanced to other interests and rights. This can be said to be a general problem when it comes to implementing children's rights in Sweden, but perhaps especially relevant when it comes to the right to participation, which has proven difficult to implement in many jurisdictions. ${ }^{11}$

The UN Committee on the Rights of the child emphasised, in its Concluding observations on Sweden from 2015, notes that article 12 is insufficiently implemented in practice, in particular as concerns custody, residence and visitation,

7 In the Legislative Bill to this reform, it was explicitly stated that the emphasis on children's rights in the Instrument of Government was seen as an important commitment in line with, and in order to fulfil the obligations in the CRC. Legislative Bill, Prop. 2009/10:80 En reformerad grundlag (8 December 2009) 188.

8 Legislative Bill, Prop. 2017/18:186 Inkorporering av FN:s konvention om barnets rättigheter (15 March 2018) 61 and 73 .

9 See Mattsson, 'Constitutional Rights for Children in Sweden' $\left(\mathrm{n}_{3}\right)$ for further discussion and also Pernilla Leviner, 'Barnkonventionen som svensk lag: En diskussion om utmaningar och möjligheter för att förverkliga barns rättigheter’ (2018) Förvaltningsrättslig tidskrift 287.

10 See Legislative Bills - Prop. 1994/95:224 Barns rätt att komma till tals (4 May 1995), Prop. 1996/97:124 Ändring i socialtjänstlagen (6 March 1997), Prop. 2002/03:53 Stärkt skydd för barn i utsatta situationer (20 February 2003), Prop. 2005/06:99 Nya vårdnadsregler (16 March 2006), Prop. 2006/07:129 Utveckling av den sociala barn- och ungdomsvården m.m. (20 June 2007), Prop. 2009/10:192 Umgängesstöd och socialtjänstens förutsättningar att tala med barn (14 April 2010) and Prop. 2012/13:10 Stärkt stöd och skydd för barn och unga (13 September 2012).

11 This is concluded by, for example, Kay Tisdall, 'Children and young people's participation: A critical consideration of Article 12' in Wouter Vandenhole and others (eds), Routledghe International Handbook of Children's Rights Studies (Routledge 2015) and Titti Mattsson, 'Some reflections on a dialogical approach to the recognition of children in the decision-making process' in Kerstin Nordlöf and Farhad Malekian (eds), The sovereignty of children in law (Cambridge Scholars Publishing 2012). 
asylum procedure and social services investigations. ${ }^{12}$ In the same concluding observations the committee also noted the following:

In the light of its general comment No.12 (2009) on the right of the child to be heard, the Committee recommends that the State party take measures to strengthen that right in accordance with article 12 of the Convention and to ensure the effective implementation of legislation recognizing the right of the child to be heard in relevant legal proceedings, including by establishing systems and/or procedures for social workers and courts to comply with the principle. ${ }^{13}$

It can be concluded that in the Swedish context, it has not been clarified in what ways children are to be guaranteed participation in public decisionmaking and it is also unclear what participation in individual cases is actually supposed to mean.

The overall aim in this chapter is to examine and discuss child participation with focus on the above described perspectives and themes - which can be labelled broadly as collective and individual - and to discuss whether reasonable conditions for participation and for children's wishes and views to be given due weight are given in Sweden today. The legal analysis, which is based on legal sources such as statutes, preparatory works, court cases and legal doctrine, both Swedish and international, is 'critical' in that it is trying to unveil not only legal uncertainties, contradictions and gaps, but also underlying norms, values and logics that affect the realisation of children's right to participation in practice. As mentioned above, article 12 of the CRC is a starting point, but, as will be made clear, there are reasons also to critically analyse the foundation of which children's right to participation according to the CRC is based on. Michael Freeman has pointed out that the CRC is a 'convenient benchmark' that contributes to fundamental improvements in the life of children all over the world, but considering that the convention is a 'beginning rather than the final word on children's rights', it is important to also reflect on its limitations. ${ }^{14}$ The view taken, with inspiration from Reynaert et al. and Vanderhole et al., ${ }^{15}$

12 UN Committee on the Rights of the Child, Concluding observations on the fifth periodic report of Sweden (6 March 2015) CRC/C/SWE/CO/5 para 19.

$13 \mathrm{CRC} / \mathrm{C} / \mathrm{SWE} / \mathrm{CO} / 05$ (n 11 ) para 20.

14 Micheal Freeman, 'Children's Rights as Human Rights: Reading the UNCRC' in Jens Qvortrup, William A. Corsaro and Michael-Sebastian Honig (eds), The Palgrave Handbook of Childhood Studies (Palgrave Macmillan 2009) 15.

15 Didier Reynaert, Maria Bouverne-De Bie and Stijn Vandevelde, 'Between 'believers' and 'opponents': Critical discussions on children's rights' (2012) 20 International Journal of 
is that the question is not only how to best implement children's right to participation, but also to analyse and question what children's right to participation can and/or should mean. ${ }^{16}$ The close connection between participation and autonomy, and the dichotomy between childhood and adulthood, having self-determination and not, will be discussed. It will be emphasised that trying to strengthen participatory rights for children, without dealing with questions relating to what decisions children should actually be able to make, risks being counterproductive, and perhaps even patronising. An overall conclusion is that, although children's rights - not least participatory rights - are on the political agenda, and in spite of the fact that children are increasingly given voice in line with article 12 of the CRC, they are not given much decision-making power, and certainly not the vote in political elections. In order for children's participatory rights to become something more than a problematic reinforcement of children's weaker position and subordination, the conclusion is that there is a need to rethink - or at least to clarify - what children's right to participation is supposed to mean in practice in Sweden today and in the future. ${ }^{17}$

\section{Collective Participatory Rights for Children-Possibilities to Influence Public Decision-Making through Right to Vote and Other Means}

When it comes to collective participatory rights for children and their possibilities to influence public decision-making, mention should be made to provisions in the goal-oriented chapter 1, section 2 in the Instrument of Government, referred to above. Apart from the specific provision on children's rights, it is also stated herein that public power 'shall be exercised with respect for the equal worth of all and the liberty and dignity of the individual' and that public institutions shall promote the opportunity for all to attain participation

Children's Rights 155; Wouter Vandenhole and others (eds), The Routledge International Handbook of Children's Rights Studies (Routledge International 2015).

16 The project has been approved by the Regional Ethical Review Board in Stockholm, see registration number 2018/704-31/5, 2018-05-17.

17 This chapter should be read together with the other chapters in this volume looking at Sweden - especially Mattsson, Constitutional Rights for Children in Sweden' (n 3) giving an overall understanding of on Children's constitutional rights in Sweden, and Schiratzki, 'The Elusive Best Interest of the Child and the Swedish Constitution' (n 53) on the principle of the best interest of the child. This principle is closely linked to children's right to be heard in individual cases as children's subjective perspective is to be included in the assessment of what is in the best interest of the child. 
and equality in society ....18 The Instrument of Government also establishes in chapter 1 , section 1 that 'all public power in Sweden proceeds from the peo$p l e$ ', and that 'Swedish democracy is founded on the free formation of opinion and on universal and equal suffrage.'19 Children are not excluded from the 'all' or the 'people' and children and young people are also included in important 'democracy participatory rights', such as freedom of expression, information, assembly and the right to demonstrate (Instrument of Government, chapter 2, section 1). ${ }^{20}$ However, there are to my knowledge no studies having looked into how children in Sweden in fact use these rights or how efficient the participatory rights through such means is in Sweden today.

\subsection{Children's Right to Vote}

Although the Swedish constitution does not directly exclude children from political participation, children are clearly not included in the most important political participation right since children do not have the right to vote or to stand for election. Chapter 3 , section 4 of the Instrument of government reads as follows:

Every Swedish citizen who is currently domiciled within the Realm or who has ever been domiciled within the Realm, and who has reached the age of eighteen, is entitled to vote in an election to the Riksdag. Only a person who is entitled to vote may be a member or alternate member of the Riksdag.

Thus, the right to vote in Sweden, as in most other countries, is linked to age of majority, i.e. legal age at which an individual becomes an adult in the legal sense, which is 18 in Sweden (Parental Code, chapter 9, section 1). Although the right to vote over the past century and a half in most countries, has been extended to other groups than men with certain income or status, including ethnic minorities and women, minors are still excluded. Denying children the most basic political right of all is, as will be described further below, in general little discussed and rarely questioned. It is probably rather assumed to be correct based on the view that children lack sufficient capacities and competence.

According to John Wall, professor of Philosophy, Religion and Childhood Studies at Rutgers University in the United States, these assumptions, which seem to influence at least 'Western' democracies, draw on thinking and writing

\footnotetext{
18 Emphasis added.

19 Emphasis added.

20 See also the CRC Articles 13-15.
} 
by Locke, Rousseau and Kant, assuming that children, in contrast to adults, lack autonomy. ${ }^{21}$ Wall also notes that even though the notion of children's rights now enjoys wide acceptance, theorists of the twentieth century, such as Rawls and Habermas, also accept and promote that suffrage should belong only to adults and that children do not possess the communicative competence to engage in political procedures of reciprocal perspective thinking. ${ }^{22}$ This is also the view taken in the International Covenant on Civil and Political Rights from 1966. Article 25 in this convention states that there should not be any 'unreasonable restrictions' on the right to vote in elections, but the comments adjoined to this convention establishes that mental incapacity as well as setting a minimum age for the vote is reasonable and constitutes legitimate grounds for exclusion. ${ }^{23}$

Even though not widely discussed, children's lack of right to vote and the 18-year-old limit can be, and has been, challenged. ${ }^{24}$ Swedish political scientist Ludvig Beckman, Sweden, notes that the criteria on who to exclude and include in the 'demos', i.e. the people on which a democracy is based, is reasonable only by virtue of the reasons behind it. ${ }^{25}$ When the legitimacy of denying children the right to vote is challenged in the literature and debate internationally two main solutions seem to be presented. One being that all individuals should have the right to vote from birth, exercised by guardians until a certain age, and the other that age-limits should be lowered to be more reasonable and in coherence with other legal age-limits.

As for age-limits it should first of all be noted that it has been lowered before in Sweden. From being 23 years old it was lowered first in 1945 to 21,

21 John Wall, 'Why Children and Youth Should Have the Right to Vote: An Argument for Proxy-Claim Suffrage' (2014) 24 Children, Youth and Environments 108.

22 See Wall (n 18) with reference to John Rawls, Political Liberalism (Columbia Univeristy Press 1996) 245 and Jurgen Habermas, Justification and application: remarks on discourse ethics (The MIт Press 1993) 64.

23 UN Human Rights Committee, CCPR General Comment No. 25: Article 25 (Participation in Public Affairs and the Right to Vote), The Right to Participate in Public Affairs, Voting Rights and the Right of Equal Access to Public Service (12 July 1996) CCPR/C/21/Rev.1/Add.7.

24 See Wall (n 18) and Ludvig Beckman, The frontiers of democracy: The right to vote and its limits (Palgrave Macmillan 2009) for more on the arguments and debate. See also Aoife Daly, 'Free and fair elections for some? The potential for voting rights for under- $18 \mathrm{~s}$ ' in David Keane and Yvonne McDermott (eds), The Challenge of Human Rights: Past, Present and Future (Edward Elgar 2012).

25 It should be noted here that Beckman (n 21) concludes that, in his view, extending the vote to children is not to the benefit of children. The basis for this view is that suffrage entails responsibilities that are not in the child's best interests. 
to 20 in 1965,19 in 1970 and then lastly to 18 in $1974 .{ }^{26}$ Today it can be argued for instance that the right to vote should be in line with the age of criminal responsibility, which in Sweden is 15. Overall, the assumption that people under 18 do not have capacity and competence is problematic as this is not a criterion for the right to vote for anyone else in the Swedish system. No adult must prove their competence to vote, even though it might be clear that the capacity to assess information and taking a stand in political questions can be questioned due to intellectual disabilities, dementia etc. ${ }^{27}$ If we are denying children the right to vote based on the argument that they do not have the capacity and competence, is it right to give adults this right without testing their capabilities and competence? If nothing else, as John Wall notes, 'it is clear that political competence does not suddenly spring into being upon a person turning 18 years old, ${ }^{28}$ and therefore, it would perhaps be better to have a flexible age limit and for capacity to be tested. It can be argued that this would be practically difficult and expensive, but are bureaucratic and economic arguments enough to deny a large number of citizens the right to vote? ${ }^{29}$ If so, at least it should be clearly stated that these are in fact the arguments, not an overall assessment that all individuals under 18 years old lack capacity to vote.

When it comes to proposals on extending the right to vote to all people from birth, Wall proposes what he calls a 'proxy-claim vote', meaning that all citizens should be granted a right to vote at birth, being exercised by a parent or guardian proxy until the child claims the right to vote by him/herself by registering to vote. Wall notes the following:

While a proxy vote may seem undemocratic through the eyes of the modernist ideal of the autonomous citizen, and while a claim for the vote in childhood challenges modernity's adult-only premises, the proposal is the best way to realise the postmodern democratic ideal of maximum inclusion of the people's lived experiences of difference. ${ }^{30}$

26 Kristina Engwall and Ingrid Söderlind, 'Barn och demokrati i ett historiskt perspektiv' in Christer Jönsson (ed), Rösträtten 80 år: Forskarantologi (Justitiedepartementet 2001).

27 For detailed consideration of these points, see Daly, 'Free and fair elections for some?' (n 21).

28 Wall (n 18$)$.

29 It should be noted here that I am not arguing here that people with intellectual disabilities should not have the right to vote, this is a discussion about the legitimacy of denying children the right to vote. 
The proposal raises many questions, perhaps as many as it resolves, one being if the right to vote should also be combined with the ability to run for office and how this would be balanced with the right not to work and right to education. Wall also raises the question of which parent would exercise the proxy vote if parents disagree and how the registration for voting would be handled, if schools should be involved etc.

It is very clear that children's right to vote is not an easy question to resolve, but it is hard not to agree with Wall in that it is undemocratic to exclude all people under 18 from voting without significantly more compelling reasons for doing so. ${ }^{31}$ Therefore, it is perhaps surprising that in a childfriendly society as Sweden, with a long tradition of emphasising democratic values and equal treatment, the right to vote for children has not been on the political agenda. There has been some discussion, mostly driven by youth organisations, whether to lower the voting age, first of all in local elections. ${ }^{32}$ A proposal to do so in national elections was also raised in the Parliament by Miljöpartiet (Green Party) in 2017, ${ }^{33}$ but this proposal was turned downed. ${ }^{34}$ In the 198 os an initiative led by the Swedish Paediatrics Association argued, quite in line with the ideas presented by Wall (see above), that children should have the right to vote from when they are born, but that this right would be exercised by a parent or other guardian acting by proxy until the child turns 18. This proposal, which as far as I know was not discussed broadly or well-known to the public, has been described and analysed by Gunnel Gustafsson, Swedish professor of Political Science. ${ }^{35}$ She concludes that a proxy-right to vote for children most probably would mean that our society would be more child- and parent-friendly, but that there are undoubtedly easier and more efficient ways to achieve this and she argues that a lowered

31 Wall (n 18$)$.

32 SOU 2016:5 Låt fler forma framtiden! (January 2016) 552. This is already the case when it comes to elections for the governing body of the Church of Sweden, in which the voting age was lowered in to 16 in 1999, see chapter 33, section 2 in Kyrkoordningen (The Church Order).

33 Proposal to the Parliament, Motion till riksdagen, 2017/18:2117, Sänkt rösträttsålder till 16 år-ge de unga större inflytande (3 October 2017). The proposal was to lower the voting age to 16 years old.

34 A proposal to lower the voting age has also been raised by Sveriges ungdomsorganisationer, The National Council of Swedish Youth Organisations, see Sveriges Ungdomsorgnaisationer, LSU, För frihet senare $i$ livet: En rapport från Sveriges ungdomsrepresentanter $i E U$.

35 Gunnel Gustafsson, 'Rösträtten och barnen' in Christer Jönsson (ed), Rösträtten 80 år: Forskarantologi (Justitiedepartementet 2001). 
age-limit is to prefer as this is more in line with the current system with individual voting. 36

\subsection{Compensatory Measures for Children's Participation}

Children and young people do clearly not have the right to vote in Sweden today. But there are other mechanisms that can be viewed as a compensation aiming at giving children the possibility to participate in public decisionmaking. First of all, as has been noted above children are not excluded from the 'all' or the 'people' having the right to for example freedom of expression etc. (Instrument of government, chapter 2, section 1). ${ }^{37}$ However, as already mentioned, there are to my knowledge no studies having analysed these rights from a child perspective in Sweden.

Another democracy mechanism, having been described as an important instrument to encourage more people, young people and children in particular, to engage in local and regional decision-making is 'citizen proposals' (medborgarförslag), which, since 2002, is regulated in the Local Government Act, 2017:725, (kommunallagen), chapter 8 , section $1 .^{38}$ This mechanism includes a right for all individuals registered in a municipality to submit proposals and to have these considered by the local government councils. As important as it could be, it has been noted that its success depends on how local governments responds to proposals, ${ }^{39}$ and there are to my knowledge few studies on how children and young people in fact use and perceive this possibility. $^{40}$

Perhaps more important, but also without being properly evaluated in Sweden, are the different forms of child and youth forums and youth parliaments. ${ }^{41}$ Another overall prerequisite of high importance for children being able to participate in public decision-making is for the school system to take on the responsibility to teach democratic processes. The responsibility of the school system will not be further discussed here, but it can be concluded that

36 One argument for lowering the age-limit pointed out by Gustafsson (n 32$)$ is the need for renewing the democracy as voter participation is low and that young people to a large extent are turning their backs to organisation in traditional political parties.

See also the CRC articles $13^{-15}$.

38 sou 2016:5 (n 29) 490.

39 Sou 2016:5 (n 29) 495; Rebecca Thorburn-Stern, Participation, Power and Attitude: Implementing Article 12 of the Convention on the Rights of the Child, vol II (Martinus Nijhoff Publishers 2017) 146.

40 Seehowever report from the Swedish Agency for Youth and Civil Society, Ungdomsstyrelsen, Unga med attityd 2013 (Ungdomsstyrelsens skriftserie 2013:3, 2013). 
also in this aspect, there is a need for further research, both legal and within other fields of science. ${ }^{42}$

\subsection{Concluding Observations on Children's Collective Right to Participation in Public Decision-Making}

To conclude, except for the right to vote which individuals under 18-years-old do clearly not have, children are not excluded from the more general participatory rights in the Swedish Constitution, and there are some compensatory mechanisms with the aim to include children in public decision-making. However, we simply do not know if this in fact results in children feeling more included and empowered. Swedish historians Engwall and Söderlind conclude that through emphasising children's right to participation, a notion of children setting the political agenda might be created, but that there is a risk that children's views are only used as an argument when in line with what adults want to achieve nevertheless. ${ }^{43}$ Borrowing the words of Kay Tisdall, Professor of Childhood policy, University of Edinburgh, there are child-focused (and probably child-friendly) mechanisms for children to be involved in public decision-making in place in Sweden today, but it can be questioned if they are child-inclusive. ${ }^{44}$ Overall, there are reasons to reflect on if the current possibilities for children to influence public decisionmaking are effective and reasonable from children's perspective or if they are mainly symbolic. In some respect, the collective participation mechanisms might even be counterproductive. Children are involved but adults are deciding, sometimes perhaps even with children's views and wishes as an argument and trump card, without having children's needs and interests at the fore. In this context, it is interesting to note that the initiative taken by Greta Thunfäll, probably known by most - a Swedish 16 year old environmental activist - took to school striking as a way to get politicians and others to listen. This can be seen as a reaction to no other ways being accesible for children and young people to have their voices heard.

So what could be done to strengthen collective participatory rights for children? Is a proxy-claim vote in line with what has been proposed by Wall described above a legitimate solution when it comes to the right to vote? Perhaps, but it can be argued that in such a system the right to vote is equally,

42 See for a historical perspective on this theme Engwall and Söderlind (n 23) 187.

43 Engwall and Söderlind (n 23) 188. This is concluded with reference to Anne-Li Lindgren and Gunilla Halldén, 'Individuella rättigheter; autonomi och beroende: Olika synsätt på barn i relation till FN:s barnkonvention' (2001) 10 Utbildning \& Demokrati 65 .

44 See Kay Tisdall, 'Subjects with agency? Children's participation in family law proceedings' (2016) 38 Journal of Social Welfare and Family Law 1. 
but differently, disempowering for those children not yet having claimed their right to vote, as parents might 'use' their right to vote. What if children, when they can claim their vote, find out that their parents have used their vote in a way which is not in line with their views and interests.

In my view, a lowered age for voting is to prefer even though the legitimacy of denying younger children the right to vote can be challenged. In the current system a reasonable age-limit could be 15 years, as this is the age for criminal responsibility, or perhaps 16 as this is the age when children can enter into contracts, etc. This also corresponds with the age when children in Sweden do no longer have a duty to go to school (skolplikt), which can be interpreted as a statement that nine years of school is sufficient. It can be noted that Aoife Daly, senior lecturer and child rights expert, Liverpool University, have argued that children should be permitted the right to vote from at least 12 years, as this is the age at which there is broad agreement that abstract thought becomes sophisticated. ${ }^{45}$

When it comes to other types of mechanisms for children to influence public decision-making there is a need for further research on how citizen proposals, youth parliaments etc. work and how children in Sweden themselves perceive their opportunities to influence local, national, regional and international politics and public decision-making. There are reasons to believe that children are both interested and capable of deciding more in our society and that this would have positive effects on our democracy. As has been noted by Aoife Daly, 'Children are an excluded group whose agency and experiences have been undervalued by the dominant group - adults. Such exclusion can breed resentment and further the apathy that contributes to low voter turnout:46 Many would agree that we live in a time where resentment and apathy are a real danger to democracy.

\section{$3 \quad$ Children's Right to Participation in Individual Cases Involving and Affecting Children-Child Protection as an Example}

\subsection{Overall on Children's Rights and Parental Responsibilities}

When it comes to children's right to participation in individual cases involving and affecting children, it should first of all be emphasised that children are also included in the above-mentioned provisions on 'the liberty and dignity of the individual', reflecting an overall fundamental right for everyone

45 Daly, Free and fair elections for some? (n 21).

46 Daly, Free and fair elections for some? (n 21). 
to self-determination and autonomy. However, it is made clear in chapter 6, section 2 of the Swedish Parental Code (föräldrabalken, 1949:381) that children are, indirectly but clearly, excluded from the right to decide in matters concerning themselves, as they are under the responsibility of their custodians (vårdnadshavare), in most cases the parents. Parental responsibility for custodians includes the right and obligation to make decisions concerning the child's personal affairs. In doing so the custodian shall increasingly take the child's views and wishes into account as the child becomes older (chapter 6, section 11), i.e. gain more co- and self-determination, but the ultimate decisional-power lies with the custodians. For example, teenagers can be deemed mature enough to decide in questions relating to reproductive health issues without involving parents, ${ }^{47}$ but when it comes to support from the Social Services, the possibilities for children and young people to receive such help without the consent of parents/custodians is much more limited. ${ }^{48}$ It is the responsibility of health care professionals, social workers, teachers and others meeting children and young people to assess children's maturity and decisional-capacity, and it can be concluded that this is done without much official guidance. ${ }^{49}$

The exclusion from autonomy and self-determination and the fact that children are under parental responsibility is probably in principle viewed as both necessary and reasonable, and the right to be heard according to article 12 of the CRC can in light of this non-self-determination, be seen as a rational compensation. But is it self-evident that people under the age of 18 should not have the right to self-determination in decisions very much affecting themselves? And is the right to be heard in article 12 of the CRC a reasonable compensation for non-self-determination or are the ideas underpinning this article in fact an example of an unreasonable reinforcement of a problematic distrust of children's abilities and capabilities?

47 SOSFS 2009:15 Socialstyrelsens föreskrifter om abort.

48 Pernilla Leviner, 'Socialtjänstens ansvar för barn och unga' in Therése Fridström Montoya (ed), Juridik $i$ socialt arbete: En introduktion (3 edn, Gleerups förlag 2018) 126; Johanna Schiratzki, Barnrättens grunder (7 edn, Studentlitteratur 2017) 98; Anna Singer, Barns rätt (Iustus 2017) 89.

49 The National Board of Health and Welfare (Socialstyrelsen) has published a handbook with the aim to support the Social Services and the health care sector in assessing children's maturity. However, it can be questioned how much concrete guiding this handbook actually gives. See Socialstyrelsen, Bedöma barns mognad för delaktighet: Kunskapsstöd för socialtjänsten, hälso- och sjukvården samt tandvården (2015). 

Child-Friendly Aim but Limited Child-Inclusion Outcome ${ }^{50}$

\subsubsection{The Legal Landscape-What Ought to Be}

To begin with, children's right to participation in line with article 12 of the CRC is emphasised as specifically important in child protection cases by the UN Committee on the Rights of the Child in its General Comment no. 12 on participation. It is stated that in such cases, the view of the child must be taken into account in order to determine the best interests of the child. ${ }^{51}$ The Committee notes that the child's right to be heard in such cases is not always taken into account by States parties and has recommended that it is to be ensured, through legislation, regulation and policy directives, that the child's views are solicited and considered. ${ }^{52}$ This is important not the least for the decision-maker to be able to determine the best interests of the child. ${ }^{53}$

In the case of Sweden, two main laws regulate the child protection system: the Social Services Act (socialtjänstlagen, 2001:453) and the Care of Young Persons Act (lag med särskilda bestämmelser om vård av unga, 1990:52). These acts are both based on the principle of voluntariness, and the absolute primary rule is that the parents are best suited to care for and represent the child (Parental Code, chapter 6). When a situation is so serious that a child or young person cannot remain with his or her parents but instead need protection and/ or specific care services, actions can be taken against the will of parents to place the child in out-of-home care. Prerequisites for such actions is regulated in the Care of Young Persons Act and can only be taken as a result of serious issues in the home, or as a result of the child's or adolescent's own destructive behaviour (section 2-3).

In the last decades, several reforms have been carried out in the child protection system to include what at a first glance can be viewed as a clear responsibility for the Social Services and Administrative Courts to hear children before making decisions in which the best interests of the child should be the primary

50 This section builds on Pernilla Leviner, 'Child participation in the Swedish child protection system: Child-friendly focus but limited child influence on outcomes' (2018) 26 International Journal of Children's Rights 136.

$5^{1} \mathrm{CRC} / \mathrm{C} / \mathrm{GC} / 12(\mathrm{n} 4)$ para 53.

$5^{2} \mathrm{CRC} / \mathrm{C} / \mathrm{GC} / 12(\mathrm{n} 4)$ para 54.

53 Focus here is mostly on the right to be involved, informed and the due weight aspect of children's participation, and less so on the best-interest-assessment that is dealt with in Johanna Schiratzki, 'The Elusive Best Interest of the Child and the Swedish Constitution' in Trude Haugli and others (eds), Children's Constitutional Rights in the Nordic Countries (Brill 2019). 
consideration. ${ }^{54}$ The starting point for these reforms has been article 12 of the CRC with the formulation in both the Social Services Act and the Care of Young Persons Act, ${ }^{55}$ which are identical, being clearly influenced by the convention.

Just how these section in the two acts should be applied is however not entirely clear. Guidelines from the National Board of Health and Welfare (Socialstyrelsen) emphasise that it is important for the Social Services to meet and talk with children involved in child protection cases, both alone and in the company of the parents, so that it is possible to assess the child's needs and best interests. ${ }^{56}$ Meetings and interviews with older children can in line with the Parental Code (chapter 6, section 11), be held without the consent of parents. Since a reform in 2013 the Social Services Act includes (chapter 11, section 10) a possibility for social workers to meet and talk also to younger children without the custodian's consent and without him/her being present. ${ }^{57}$ This reform was explicitly driven by an aim to guarantee children the right to participation, but the possibility to talk to children without the consent of their parents is clearly an exception to the main rule that child protection investigations is to be conducted in line with the principle of voluntariness. ${ }^{58}$ It has been noted that the reform and the introduction of this new possibility lacks clarity on how to handle situations when parents in fact do oppose the Social Services talking to their children. ${ }^{59}$

Closely connected to children's right to be heard and to participate in individual cases is of course the possibility for children to be legally represented by a representative who can express the child's specific interests and needs, and who can also act on behalf of the child with respect to measures to be taken, appeals etc. This is also emphasised in article 12 of the CRC where it is stated that children shall be given the opportunity to be heard, directly or

54 See, for example, Legislative Bills, Prop. 1994/95:224 Prop. 1996/97:124, Prop. 2002/ 03:53, Prop. 2006/o7:129, Prop. 2009/10:192 and Prop. 2012/13:10 (n 9). In June 2015, a Legislative Inquiry, SOU 2015:71 Barns och ungas rätt vid tvångsvård: Förslag till ny LVU was presented which also includes proposals to strengthen children's rights and perspectives. This has not yet led to a Legislative Bill and reform.

55 The Social Services Act, chapter 11, section 10 and the Care of Young Persons Act, section 36 .

56 SOSFS 2014:6 Socialstyrelsens allmänna råd om handläggning av ärenden som gäller barn och unga.

57 There are no specific age limits connected to this possibility, and it is for the Social Services to assess and decide - without more than overall guidelines indicating that age, maturity and the questions at hand is to be considered - when interviews can and should be held without parental consent.

$5^{8}$ See Legislative Bill, Prop. 2009/10:192 (n 9) 19. It should be noted that it can never be acceptable to force a child to meet and talk to the Social Services.

59 See further in Leviner, 'Socialtjänstens ansvar för barn och unga' (n 45). 
through a representative. ${ }^{60}$ According to Swedish child protection regulations, both children and parents have the right to be represented by a public representative (offentligt biträde) when involuntary internventions according to the Care of Young Persons Act are deemed necessary. ${ }^{61}$ Such representatives are publicly financed, ${ }^{62}$ and it is the Administrative court (förvaltningsrätten) that appoints the specific representative. ${ }^{63}$ However, important to note is that a public representative will only be appointed for the child (and his/her parents) if parents do not consent to interventions, i.e. only in cases with involuntary interventions according to the Care of Young Persons Act. When out-of-homeplacements are in line with what parents want, and provided according to the Social Services Act, children will not have a public representative and thereby possibly less guarantees for participation, even though it might be against the child's wishes and thereby involuntary in that sense.

The role of the public representative for children will differ depending on whether the child is under or over 15 years of age. For children under 15 , the public representative, without any special appointment, also serves as the child's guardian (ställföreträdare) in questions relating to the care proceedings (the Care of Young Persons Act, section 36 ). The preparatory works state that the purpose of this under-15-representative is to provide the child with an independent position in the proceedings, and that through the representative, the court shall be able to obtain an 'objective' description of the child's situation. ${ }^{64}$ The representative can thereby make decisions on matters related to the investigation, while also supporting the child in the process. In addition

6o The Committee on the Rights of the Child have emphasised in the General Comment no. 12 that in cases where conflicts of interest can arise between children and parents, as is often the case in child protection proceedings, there is reason to appoint a separate representative for the child, see CRC/C/GC/12 (n 4) paras 35-37.

61 The main rule is that the child shall have his or her own representative (the Care of Young Persons Act, Sections 36 and 39), ie not the same representative as the parents.

62 It has been noted, however, that the compensation for this work is far from adequate with respect to the effort that representatives put into (or would want to put into) the job in order to fully carry out the assignment. Sebastian Wejedal and Allison Östlund, Advokatens roll: Om ändamålsenlig rollfördelning i mål om tvångsvård av barn (Santérus 2016) 137 .

63 As such the court is very influential in deciding who will be appointed, but also in determining the amount of compensation to be given to the representative (Act on Public Representation, 1996:1620, Section 4).

64 Legislative Bill, Prop. 1994/95:224 (n 9) 26 and 44. According to the very same text in the preparatory works, the representative is also duty-bound to ensure the child's right of appeal. With respect to appeals, it should be noted that the Swedish Supreme Administrative Court in case HFD 2014 ref. 38 established that a child under 15 years of age has the right to appeal a decision on placement in care in accordance with the Care 
to presenting the client's wishes, the representative for children under 15 shall also arrive at his or her own assessment of the child's best interest. This means that the representative has a problematic contradictory task. The representative will present his or her assessment of the child's best interests to the court, which might well go against what the child expresses as his or her will. There are no guidelines regarding what weight children's own wishes should be given in this assessment, which is especially problematic given that the representatives' assessments seem to play an important role in the courts' final decision. ${ }^{65}$ This means that there is a risk that children under 15 have limited possibilities to influence decisions, as their own representatives can present an assessment that goes against their wishes. It should be noted that the 15 year age limit, is high in an international comparison. ${ }^{66}$ This can be seen as a result of an overall will in Sweden to protect younger children from involvement, both in the sense of influencing decisions and having to take part in proceedings, which perhaps can be argued to be child-friendly and reasonable in some cases, but it is certainly not child-inclusive.

There are also other problematic aspects of the public representatives' roles and powers. First of all, it can be concluded the authority given to public representatives is rather uncertain and it is not clear what the actual role of the representative is. ${ }^{67}$ One specific problem is also late appointments of the public representatives. As a representative is only to be appointed when involuntary interventions are considered, or in practice when deemed necessary, children (and parents) will not receive representation until after already having been placed into out-of-home careon emergency orders, not during the investigative phase. ${ }^{68}$ This is problematic as it is questionable that no one except the parents will represent the child during the very time when the child's situation is being investigated - not least when insufficient parental care and risk in the home environment is the reason for the investigation. It can also be noted that even though the UN Committee in General Comment no. 12 emphasise that professionals representing children should possess adequate knowledge of children's rights and should be able to communicate with children on their

of Young Persons Act, even if the public representative, aslo acting as the child's guardian, is of the opinion that the decision should stand.

65 The National Board of Health and Welfare, Socialstyrelsen, Barnets rätt och LVU: Om barnet i rättsprocessen (Socialstyrelsen 2009).

66 See Leviner, Child participation in the Swedish child protection system (n 47).

67 See Leviner, Child participation in the Swedish child protection system (n 47).

68 See Anna Hollander, 'Att tillvarata barnets rätt och bästa: Om det komplexa uppdraget att företräda barn i rättsliga processer' in Anna Hollander, Rolf Nygren and Lena Olsen (eds), Barn och rätt (Iustus 2004). 
level of understanding, ${ }^{69}$ Swedish law does not place any formal requirements on public representatives' competence. ${ }^{70}$

\subsubsection{The Application of the Law - the Aim and the Gap}

As has been pointed out above, the regulations of the child protection system set out a responsibility for the Social Services and the courts to fulfil children's rights to participation. However, it can already from an analysis of legal sources be concluded that the regulations are unclear and problematic in many aspects, and of course, this raises questions about how children's right to participation in the child protection system is fulfilled in practice. Do the regulations lead to children being informed, heard and feeling involved? Do children get possibilities to influence decisions made about them?

Unfortunately, research on if and how children are heard in the Swedish child protection system, as well as what weight is given to their wishes is limited, which perhaps says something in itself when it comes to the interest in children's right to participation. Even though studies show that to a greater degree than previously the Social Services meet and speak with children, there are indications that children in the child protection system do not experience being informed and/or provided with possibilities for participation. ${ }^{71}$ There are indications that children's wishes and opinions only seem to be clearly presented in the child protection investigations when they correspond to the position already taken by the Social Services, and thereby only influence decisions made when in line with what has been deemed necessary. ${ }^{72}$

Limitations as to children's participation seem to apply, in particular, for children in out-of-home placements, who report often not being informed, heard or listened to. ${ }^{73}$ This is definitely problematic, not the least in cases

$69 \mathrm{CRC} / \mathrm{C} / \mathrm{GC} / 12(\mathrm{n} 4)$ para 36.

70 See Sou 2015:71 (n 51) 87 and 493.

71 Elin Hultman, Barnperspektiv i barnavårdsutredningar: Med barns hälsa och upplevelser $i$ fokus (Linköpings universitet 2013); Pernilla Leviner, Rättsliga dilemman i socialtjänstens barnskyddsarbete (Jure förlag AB 2011); Sofia Enell, Barnet i utredningen: En uppföljningsstudie om barns ställning i barnavårdsutredningar genomförda i BBIC, FoU-rapport 20og:6 (Luppen Kunskapscentrum 2009).

72 Leviner, Rättsliga dilemman i socialtjänstens barnskyddsarbete (n 68) 287. This has also been noted in international studies, see, for example, Judith Masson, 'Representation of children in England: Protecting children in child protection proceedings' (2000) 34 Family Law Quarterly 467. For an international overview of this issue, see Aoife Daly, Children, Autonomy and the Courts: Beyond the Right to be Heard, vol II (Martinus Nijhoff Publishers 2018).

73 Barnombudsmannen, Bakom fasaden: Barn och ungdomar $i$ den sociala barnavården berättar (Barnombudsmannen 2011) 39 . 
where children are taken into out-of-home care against the will of their parents and themselves, as in these cases children and young people have a public representative, who in line with what has been described above has the task to guarantee participation for the children that they represent. However, studies having looked at the role and work of such public representatives show that there are several problems in how the system with public representatives in child protection cases work in practice. Late appointments is one. As has been described above, the regulations on public representatives lead to that representatives in most cases will only to be appointed when children have already been placed into out-of-home care on emergency orders, not during the investigative phase. ${ }^{74}$ Apart from this overall problem, a report from the The National Board of Health and Welfare (Socialstyrelsen) show that even when a representative is appointed, children do not always get to meet with their representative. ${ }^{75}$

In addition to these observations, a study by Wejedal and Östlund from 2016 examining Swedish court judgments in child protection cases concludes that public representatives for children assume a problematic role as the child's 'protector' by asserting their own perception of the child's best interest over the child's subjective will. ${ }^{76}$ These results confirm what has been noted by Mattsson that there is a risk that lawyers representing children consciously or unconsciously suppress the information given by the child. ${ }^{77}$ Similar problematic results can be found in a student master's thesis from Stockholm University from 2016, also being based on an analysis of court judgments in child protection cases from Swedish administrative courts. It is shown that for children under 15 , the judgments often lack information about the child's own opinion and view of their own situation, nor is there evidence in the judgments that the court provides weight to the child's viewpoint and wishes. ${ }^{78}$

\footnotetext{
74 See Hollander (n 65).

75 Socialstyrelsen, Barns rätt och LVU (n 62).

76 Wejedal \& Östlund (n 59).

77 Titti Mattsson, Barnet och rättsprocessen (Juristförlaget i Lund 2002) 437 and 451.

78 Emma Hawia-Svensson, Barns rätt att komma till tals $i$ LVU-mål: En studie av rättslig reglering och kammarrättspraxis (2016). It should be noted that verbal information in these cases might have been submitted in the court hearing, but still not mentioned in the written judgements, although it should reflect everything presented to the court as well as the full basis for the court's decision (Administrative Court Procedure Act, 1971:291, section 30 ).
} 
In conclusion, the Swedish child protection regulations are clear that the Social Services should meet and talk to children. However, as have been described, there are many legal unclarities and, not surprisingly, limitations in how children's participation right is fulfilled in practice. An overall problem is that it is not made clear what is to be achieved by involving and talking to children, especially not when it comes to how the child's own statements should be handled and assessed and what weight children's wishes and views should be given. On this point, the legal sources provide no guidance.

Thus, it can be concluded that even though the right to be heard has been transformed into Swedish child protection regulations, and in spite of many implementation efforts, there are indications that children's participatory rights is not fulfilled. Although perhaps specifically problematic in the child protection system, difficulties to guarantee children's right to participation are not limited to this field of law. As noted in the introduction to this chapter, the UN Committee on the Rights of the child emphasised in its concluding observations on Sweden from 2015 that article 12 is insufficiently implemented in social services investigations. ${ }^{79}$ This indicates, borrowing again the words of Kay Tisdall, that even though Swedish child protection authorities seem to be more child focused then in previous decades, there are still limitations as to the child inclusiveness. ${ }^{80}$

So why is the right to participation so difficult to fulfil in individual cases? Contrary to high hopes voiced by the Swedish Government and child rights organisations in Sweden suggesting that incorporation of the CRC into Swedish Law will make a difference also when it comes to children's right to participation, I think the problem might be connected to the very core of article 12 , and therefore also to its previous transformation and definitely remaining after the incorporation of the CRC into Swedish law. There are problematic aspects in the foundation on which child participation in individual cases according to the CRC is built. This risk not only being a poor compensation for self-determination, but also a having counterproductive elements in the sense that children might perceive that they in fact have no possibilities to influence decisions made about them - being given voice but then still no choice.

It can be argued that Swedish law should clarify what article 12 is to mean and what is to be fulfilled in the national context in different fields of law,

$79 \mathrm{CRC} / \mathrm{C} / \mathrm{SWE} / \mathrm{CO} / 5$ (n 11$)$ para 19.

8o Tisdall, 'Subjects with agency?' (n 41). 
but this has clearly not happened. It has not been made clear what is to be achieved and how children's views and wishes are to be weighed. Aoife Daly has proposed that a 'children's autonomy principle' should guide child participation in decisions in which the best interest of the child is the primary consideration, for example, child protection cases. According to this principle, children should get to choose - if they wish - how they are involved (process autonomy) and the outcome (outcome autonomy) unless it is likely that significant harm will arise from their wishes. ${ }^{81}$ This principle can be compared to what has been suggested by Professor Titti Mattsson, when arguing for a dialogical approach to child participation in individual cases and a 'participation veto' that would mean that a child can enter into a decision-making process under a rule demanding participation upon request of the child. ${ }^{82}$

Even in line with the children autonomy principle and participation veto, participation for children is not the same thing as a right to always make autonomous decisions, but it must be emphasised that if authorities and courts make decisions that are not consistent with what the child wants, which, in turn, activates a need and a right for the child to have such decisions adequately explained and to participate in its consequences. ${ }^{83}$ If the Swedish legislator as well as courts and authorities considered such approaches to children's participation rights, this would likely help to bring focus to the questions around what we are trying to achieve when we are seeking to implement children's participation rights.

\section{4 Concluding Discussion - Voice but No Choice and Child-Friendly but Not Child-Inclusive}

It can be concluded that there are challenges in implementing children's right to participation in Sweden, both on an overall collective political participatory level and in hearing children in individual child protection cases. Today, there is a risk that children are given voice, but limited choice and definitely no vote. The risk is also that their perspectives and wishes are only included and taken into account when in line with what adults have already decided in individual cases and/or only an argument for what adults want when it comes to public

\footnotetext{
81 Daly, Children, Autonomy and the Courts (n 69).

82 Mattsson, 'Some reflections on a dialogical approach to the recognition of children in the decision-making process' (n 10).

83 This is also emphasised in UN Committee on the Rights of the Child, General comment no. 12 (n 4) para 45.
} 
decision-making. In other words, we might provide children with political arenas and initiatives, as well as making sure that professionals, such as social workers and judges, meet and talk to children asking them what they want, but then deciding 'over their heads'. This can be seen as counterproductive in the sense that children might perceive themselves having less possibilities to influence decisions made when being given the symbolic arenas to give voice to what they want but not 'sitting at the table', having a real say when decisions are made. Perhaps this counterproductive result of children's right to participation in practice is even more evident in the Nordic overall 'child-friendly' countries. Having become more and more child-friendly is clearly not a guarantee of being child-inclusive. ${ }^{84}$

The aim with this chapter has been to discuss whether reasonable conditions for child political participation and for children's wishes and views to be given due weight in individual cases are given in Sweden today, the overall question being if legal explanations can be found for the problems identified, and consequently what the legal solutions might be. As has been made clear in the analysis in this chapter, there is no constitutional protection for children's right to participation today in Sweden. It has been pointed out both here and in Mattsson's chapter in this volume ${ }^{85}$ that the CRC will not be given constitutional status or protection when incorporated into Swedish law in January 2020. Perhaps this would have made a difference, but the overall conclusion is that there is a need to rethink children's right to participation beyond both giving children an arena for being involved in public decision-making and hearing children in individual cases. The way the participation right for children is conceptualised today - both in the CRC and in Swedish law - there is a risk that this right will never develop and transform into actually giving children the possibilities to influence decisions that affects their lives and futures, no matter how much efforts legislators and public authorities put into implementation measures. As has been discussed, there is even a risk that the way children's right to participation is applied in practice today in fact works as a problematic reinforcement of children's weaker position and subordination.

Also, it must be noted as Virginia Morrow, researcher in Childhood studies, University of Oxford, has pointed out that participation is assumed to be a good thing that leads to an increased awareness of choices and also contributes to well-being, but that this is problematic for children given that they are

84 Leviner, 'Child participation in the Swedish child protection system' (n 47).

85 Mattsson, Titti Mattsson, 'Constitutional Rights for Children in Sweden' (n 3 ). 
excluded from one the key markers of citizenship, the right to vote. ${ }^{86}$ This illuminates the connection between participation in public decision-making and individual cases such as child protection, and possibly highlights the fact that participation must be seen not as an abstract end in itself, but rather in the context of how children and adults are interconnected, and the ways in which adult structures and institutions constrain children. ${ }^{87}$ Children are dependent on adults, both by the internal limitations of childhood (at least for younger children) and by how society and the 'system' is set up (not the least the legal), being established and controlled by adults. Being given the right to participation in this context might seem contradictive.

But there are alternative ways of thinking about child participation and how children can influence decisions affecting them - either their lives and futures as a group, or in individual cases such as decisions made in the child protection system. As has been noted above, Daly has proposed that a 'children's autonomy principle' should guide child participation in decisions in which the best interest of the child is the primary consideration, i.e. individual cases, for example in the child protection system. ${ }^{88}$ This is a shift in how to think about child participation, letting self-determination be the main-rule instead of seeing the right to participation as compensation for incapacity and non-self-determination. Such a children's autonomy principle could also guide children's participation in public decision-making and perhaps this should be emphasised on the constitutional level, strengthening the above-mentioned goal-oriented provision in chapter 1, section 2 in our Instrument of Government. If making clear here that a children's autonomy principle should guide Swedish law on matters affecting children could be a shift in how to think about children's rights. Although participation in line with this principle does not mean that children always are to be given the possibility to make autonomous decisions, I truly believe that it would increasingly empower and avoid unnecessarily excluding children from making decisions that they are well equipped to make.

There is a need to ask why participation for children is so difficult to achieve. At present, there is an obvious risk that 'in the name of their best interests'

86 Virginia Morrow, 'Dilemmas in Children's Participation in England' in Antonella Invernizzi and Jane Williams (eds), Children and Citizenship (Sage Publications 2008).

87 Morrow (n 82).

88 Daly, Children, Autonomy and the Courts (n 69). According to this principle children should get to choose - if they wish - how they are involved (process autonomy) and the outcome (outcome autonomy) unless it is likely that significant harm will arise from their wishes. 
we protect children by not involving them, but it might be that the real reason is that we want to protect the system from change. The resistance might be connected to a fear of what strengthened rights for children would mean to society. I strongly believe that now is the time to re-think and reformulate children's involvement in decisions affecting them in order to move away from symbolic approaches to substantial child participation.

\section{References}

Barnombudsmannen, Bakom fasaden: Barn och ungdomar i den sociala barnavården berättar (Barnombudsmannen 2011).

Beckman L, The frontiers of democracy: The right to vote and its limits (Palgrave Macmillan 2009).

Daly A, 'Free and fair elections for some? The potential for voting rights for under-18s' in David Keane and Yvonne McDermott (eds), The Challenge of Human Rights: Past, Present and Future (Edward Elgar 2012).

Daly A, A Commentary on the United Nations Convention on the Rights of the Child, Article 15: The Right to Freedom of Association and Peaceful Assembly (Brill Nijhofff 2016).

Daly A, Children, Autonomy and the Courts: Beyond the Right to be Heard, vol II (Martinus Nijhoff Publishers 2018).

Enell S, Barnet i utredningen: En uppföljningsstudie om barns ställning i barnavårdsutredningargenomförda iBBIC, FoU-rapport 20og:6 (Luppen Kunskapscentrum 2009).

Engwall K and Söderlind I, 'Barn och demokrati i ett historiskt perspektiv' in C Jönsson (ed), Rösträtten 80 år: Forskarantologi (Justitiedepartementet 2001).

Freeman M, 'Children's Rights as Human Rights: Reading the UNCRC' in Jens Qvortrup, William A. Corsaro and Michael-Sebastian Honig (eds), The Palgrave Handbook of Childhood Studies (Palgrave Macmillan 20og).

Gustafsson G, 'Rösträtten och barnen' in Christer Jönsson (ed), Rösträtten 80 år: Forskarantologi (Justitiedepartementet 2001).

Habermas J, Justification and application: remarks on discourse ethics (The MIT Press 1993).

Hawia-Svensson E, Barns rätt att komma till tals i LVU-mål: En studie av rättslig reglering och kammarrättspraxis (2016).

Hollander A, 'Att tillvarata barnets rätt och bästa: Om det komplexa uppdraget att företräda barn i rättsliga processer' in Anna Hollander, Rolf Nygren and Lena Olsen (eds), Barn och rätt (Iustus 2004).

Hultman E, Barnperspektiv i barnavårdsutredningar: Med barns hälsa och upplevelser i fokus (Linköpings universitet 2013).

Leviner P, Rättsliga dilemman i socialtjänstens barnskyddsarbete (Jure förlag AB 2011). 
Leviner P, 'Barnkonventionen som svensk lag: En diskussion om utmaningar och möjligheter för att förverkliga barns rättigheter' [2018] Förvaltningsrättslig tidskrift 287 .

Leviner P, 'Child participation in the Swedish child protection system: Child-friendly focus but limited child influence on outcomes' (2018) 26 International Journal of Children's Rights 136.

Leviner P, Socialtjänstens ansvar för barn och unga' in Montoya Therese Fridström (ed), Juridik $i$ socialt arbete: En introduktion (3 edn, Gleerups förlag 2018).

Lindgren A-L and Halldén G, 'Individuella rättigheter; autonomi och beroende: Olika synsätt på barn i relation till FN:s barnkonvention' (2001) 10 Utbildning \& Demokrati 65 .

Masson J, 'Representation of children in England: protecting children in child protection proceedings' (2000) 34 Family Law Quarterly 467.

Mattsson T, 'Constitutional Rights for Children in Sweden' in Trude Haugli and others (eds), Children's Constitutional Rights in the Nordic Countries (Brill 2019).

Mattsson T, Barnet och rättsprocessen (Juristförlaget i Lund 2002).

Mattsson T, 'Some reflections on a dialogical approach to the recognition of children in the decision-making process' in Kerstin Nordlöf and Farhad Malekian (eds), The sovereignty of children in law (Cambridge Scholars Publishing 2012).

Morrow V, 'Dilemmas in Children's Participation in England' in Antonella Invernizzi and Jane Williams (eds), Children and Citizenship (Sage Publications 2008).

Motion till riksdagen, 2017/18:2117, Sänkt rösträttsålder till 16 år - ge de unga större inflytande (3 October 2017).

Prop. 1994/95:224 Barns rätt att komma till tals (4 May 1995).

Prop. 1996/97:124 Ändring i socialtjänstlagen (6 March 1997).

Prop. 2002/03:53 Stärkt skydd för barn i utsatta situationer (20 February 2003).

Prop. 2005/o6:99 Nya vårdnadsregler (16 March 2006).

Prop. 2006/o7:129 Utveckling av den sociala barn- och ungdomsvården m.m. (20 June 2007).

Prop. 2009/10:80 En reformerad grundlag (8 December 2009).

Prop. 2009/10:192 Umgängesstöd och socialtjänstens förutsättningar att tala med barn (14 April 2010).

Prop. 2012/13:10 Stärkt stöd och skydd för barn och unga (13 September 2012).

Prop. 2017/18:186 Inkorporering av FN:s konvention om barnets rättigheter (15 March 2018).

Rawls J, Political Liberalism (Columbia Univeristy Press 1996).

Reynaert D, Bouverne-De Bie M and Vandevelde S, 'Between 'believers' and 'opponents': Critical discussions on children's rights' (2012) 20 International Journal of Children's Rights 155 .

Schiratzki J, Barnrättens grunder (7 edn, Studentlitteratur 2017). 
Schiratzki J, 'The Elusive Best Interest of the Child and the Swedish Constitution' in Trude Haugli and others (eds), Children's Constitutional Rights in the Nordic Countries (Brill 2019).

Singer A, Barns rätt (Iustus 2017).

Socialstyrelsen, Barnets rätt och LVU: Om barnet i rättsprocessen (Socialstyrelsen 2009).

Socialstyrelsen, Bedöma barns mognad för delaktighet: Kunskapsstöd för socialtjänsten, hälso- och sjukvården samt tandvården (2015).

SOU 2016:5 Låt fler forma framtiden!.

SOU 2015:71 Barns och ungas rätt vid tvångsvård: Förslag till ny LVU.

Sveriges Ungdomsorgnaisationer L, För frihet senare i livet: En rapport från Sveriges ungdomsrepresentanter i $E U$ (2017).

Thorburn-Stern R, Participation, Power and Attitude: Implementing Article 12 of the Convention on the Rights of the Child, vol II (Martinus Nijhoff Publishers 2017).

Tisdall K, 'Children and young people's participation: A critical consideration of Article 12' in Wouter Vandenhole and others (eds), Routledghe International Handbook of Children's Rights Studies (Routledge 2015).

Tisdall K, 'Subjects with agency? Children's participation in family law proceedings' (2016) 38 Journal of Social Welfare \& Family Law 1.

UN Committee on the Rights of the Child, General comment No. 12: The right of the child to be heard (1 July 2009) CRC/C/GC/12.

UN Committee on the Rights of the Child, Concluding observations on the fifth periodic report of Sweden (6 March 2015) CRC/C/SWE/CO/5.

UN Human Rights Committee, CCPR General Comment no. 25: Article 25 (Participation in Public Affairs and the Right to Vote), The Right to Participate in Public Affairs, Voting Rights and the Right of Equal Access to Public Service (12 July 1996) CCPR/C/21/ Rev.1/Add.7.

Ungdomsstyrelsen, Unga med attityd 2013 (Ungdomsstyrelsens skriftserie 20133, 2013).

Vandenhole W and others (eds), The Routledge International Handbook of Children's Rights Studies (Routledge International 2015).

Wall J, 'Why Children and Youth Should Have the Right to Vote: An Argument for Proxy-Claim Suffrage' (2014) 24 Children, Youth and Environments 108.

Wejedal S and Östlund A, Advokatens roll: Om ändamålsenlig rollfördelning i mål om tvångsvård av barn (Santérus 2016). 